\title{
A CRITICAL REVIEW ON PHYSIOLOGICAL IMPORTANCE OF TRIDOSHA IN CONTEXT TO DIGESTION
}

\author{
MARWADI VJ ${ }^{1 *}$, RAOLE VV ${ }^{2}$ AND GAIROLA G ${ }^{3}$
}

1: PG Scholar, Department Of Kriya Sharir, Parul Institute Of Ayurveda, Vadodara

2: Guide \& Professor, Department Of Kriya Sharira, Parul Institute Of Ayurveda, Vadodara

3: Assistant Professor, Department of Kriya Sharir, Coer Medical College and Hospital, Uttarakhand

*Corresponding Author: Dr. Vaidehi V Raole; E Mail: vaidehi.raole@paruluniversity.ac.in

Received 12 ${ }^{\text {th }}$ Dec. 2021; Revised 14 ${ }^{\text {th }}$ Jan. 2022; Accepted $7^{\text {th }}$ Feb. 2022; Available online $5^{\text {th }}$ March 2022

https://doi.org/10.31032/IJBPAS/2022/11.3.1066

\begin{abstract}
Ayurveda is the "science of life". Its principles are based on the concept of Tridoshas ie. vata, pitta and kapha. These doshas are nothing but a mixture of panchmahabhutas - Prithvi, apa, teja, Vayu, and akasha in many variations. These doshas regulate the physiological, mental and emotional functions and decide the condition of the mind.

Ayurveda is not merely the science for treating illness but also the science of life which helps to maintain health. The primary aim of Ayurveda is to maintain the health of a healthy individual. Ahara is the most important component and responsible for the growth and development of the body. Each person has a different amount of vata, pitta or kapha in the body, and this depends on the food the person consumes. A individual with a balance of all three doshas should consume food to maintain a balance of Tridoshas. An individual diet should contain Gunas (characteristics) and Rasas (taste) that will maintain the doshas in a balanced state. The food consumed by an individual should contain a significant quantity of rasa that is contrary to the inherent nature of the doshas that constitute his Prakriti. In order to stabilize a specific dosha, it is important to prescribe a person with the food of the taste that helps to pacify the doshas.
\end{abstract}

Keywords: Tridosha, Aharapachana, Paka, Digestion 


\section{INTRODUCTION:}

Ayurveda is the traditional ancient Indian system of health science. The Ayurvedic holistic healthcare approach stresses, balancing the body mind and spirit to cure and avoid sickness. Diet and lifestyle are important factors assumed to affect susceptibility to many diseases in the current era. According to Ayurveda, digestion is the mechanism by which the food we eat is broken down into a simpler and absorbable one. Agni and Tridosha play an important role in digestion and are responsible for the good health of a person without proper digestion Many diseases may be affected. An individual with a reasonably balanced digestion and whose body humours are in a state of equilibrium and in whom the fundamental vital fluids course in normal state and quantity is said to be a healthy person, followed by the regular processes of secretion, organic activity and intellection. $^{[1]}$ Increased demand for ayurveda science in the present society is required to understand the depth of ayurvedic principle in an easy way .hence an effort has been made to ascertain and establish the knowledge regarding physiological function of Tridoshas in context to Digestion.

\section{AIM AND OBJECTIVES:}

- To enlight the role of Tridosha in process of Digestion.

\section{MATERIALS AND METHODS :}

All the Ayurvedic Samhita, Authentic books , Modern text books, research articles and related topics and journals are compiled to explore and understand the role of Tridosha in digestion.

\section{REVIEW OF LITERATURE:-}

Food is life of living being. All live animals yearn for food. Food offers them color, luster, speech, life, innovation, happiness, nourishment, strength, intelligence etc. ${ }^{[2][36]}$ It is true that food is capable of offering nourishment to used body entities, luster, strength, good color of skin etc. all these things are possible only if food digests, not otherwise. ${ }^{[37]}$ Man remains healthy with appropriate food. Even if drugs are introduced to a disease person he cannot get cured without food. ${ }^{[38]}$ This is reason why physicians call food as great medicine. one can arrest vitiation of dosha at the level of accumulation. ${ }^{[3]}$ This means food can be adjusted in such a fashion that it fulfils need of body and brings about the homeostatic condition in body physiology. ${ }^{[40]}$ Aharaparinama is ultimate fate of eaten food in living body. if eaten food is as per requisites of body entities, ultimate fate of food facilitate health. Otherwise eaten food could be problematic to health. ${ }^{[17]}$ Ingested 
food is bio-transformed into body entities. If food bears qualities facilitating body entities, it is able to nourish and replenish these body entities. If food bears qualities opposite to body entities, such food keeps these body entities ill nourished. ${ }^{[4]}$ After the digestion of food it is divided in two parts namely, Sara and Kitta . Body entities are originated from both parts of food body entities originated from Sara portion of food are called prasaadabhutah and body entities originated from kitta portion of food are called Malabhutah. ${ }^{[5]}$ From the essence of digested food, Seven Dhatuvaha, Matter required for special senses and Upadhatu are generated. ${ }^{[39]}$

The purpose of Ayurveda science is to maintain the health of healthy person and cure the disease of diseased one. ${ }^{[34]}$ In ayurveda health is a state where Dosha, Agni, Dhatu, Waste products, all physiological functions should be in homeostatic state and soul, sense organ and mind should be in a state of total wellbeing. ${ }^{[35]}$ Tridosha are responsible for the physical and mental growth. they govern the creation, maintenance and destruction of bodily tissue and elimination of waste products from the body. ${ }^{[41]}$ They circulate through out the body. All functions of living body are initiated, carried out and controlled by Doshas. ${ }^{[6]}$
Tridoshas are biological gears of living body. when they are in physiological condition, maintain homeostasis of body whereas they become enemies of body when they break their normal limits ${ }^{[18]}$. Let us review role of subtypes of each Dosha in digestion.

\section{PRANA VATA:-}

Prana is a type of vayu which sustains whole body and which freely circulated in the mouth. Location of prana vata is head, chest, neck, tongue, mouth and nose . ${ }^{[7][19]}$ Inspiration and deglutition are most important functions of prana vata. It functions for ingestion of food and for survival of living being. ${ }^{[8][20]}$ Gati of Prana vata is Anulomana that is upward to downward direction, which helps in entering the food from outside to inside or from upward to downward direction. ${ }^{[21]}$ Once food is taken in mouth Prana vayu directs this food to stomach. ${ }^{[42]}$ Food is one of three Bahyaprana namely, Air, Food and water. Prana vayu helps this Prana to enter inside body through mouth and inside digestive organ, stomach, through esophagus. ${ }^{[43]}$

\section{SAMANA VATA:-}

Location of Samana vata is in amashaya (stomach) and pakwashaya (small intestine), in vicinity of Agni. ${ }^{[44][45]}$ In GI tract it holds food, digests it, separates it into absorbable and non- absorbable portion, and sends it 
further in lower part of intestine. It also induces and strengthens digestive fire. ${ }^{[9]}$ The term Samana means "samanthad kosthesamyaksamamvaaniti, iti samanah" which denotes prevalent all around or which equalizes into one whatever we eat. ${ }^{[22]}$ Samana vata helps in ingestion of food into GIT with the help of Prana vayu. It helps in movement of GI contains by the contraction of muscle with the help of Vyana vayu. It also helps in movement of waste products in their respective srotas by the help of Apana vayu. $^{[23]}$

\section{APANA VATA :-}

The vayu which controls the activity in the lower part of body is called as Apana vata. ${ }^{[46]}$ The vishesha sthana of Apana vata is mentioned as Apana pradesh and also said to move in sroni (pelvic area), Basti ( bladder), Medhra, Uru( thighs). ${ }^{[24]}$ The function of Apana vata is said to be Niskramana of sukra (semen), Arthava ( menstrual flow), Shakrit (feces), Mutra (urine), Garbha (fetus). ${ }^{[25]}$ After sara - kitta vibhajana, solid waste is formed. When there is urge for defecation, stool is propelled out through anus. The physiology behind the defecation can be corelated to the Shakrit Niskramana karma of Apana vata. ${ }^{[26]}$ vitiation of Apana vata leads to retention of feces. ${ }^{[10]}$
Prana, Apana \& Samana when they are located in their own places, working normally; play important role in digestion . hence these three types of vata should be looked after properly. ${ }^{[11]}$

\section{PACHAK PITTA :-}

Grahani which is located between Amashaya and pakwashaya, is the site of Pacaka pitta

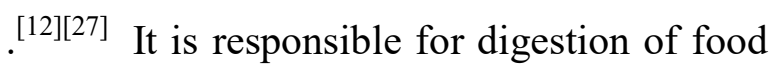
hence named as Pachaka pitta. It divides digested food into two portions . one portion is called Sara, which actually nourishes concerned Dhatu and Upadhatu etc. other portion which is not used is called kitta portion. [13][28] Pachaka pitta gives stimulation, support, and strength to other types of pitta. As it is having predominance of teja mahabhuta, fiery in nature \& devoid of liquid part called Anala which supports functions of other subtypes of pitta. ${ }^{[14][29]}$ As ayurveda is based on functional understanding Pachaka pitta can be correlated with digestive enzymes. ${ }^{[30]}$

\section{KLEDAKA KAPHA :-}

Kapha, which is situated in stomach, is called Kledaka. ${ }^{[31][32]}$ This Kapha is responsible for softening food and breaking its complexity ${ }^{[15]}$ In stomach this kapha wraps food and protect stomach from burning effect of Pachaka pitta just as moon counters sun with its coolness. It moist food and helps to break 
complex food particles into simple moistens the food, disintegrates and breaks it molecules. ${ }^{[16]}$ The liquid components of the can be considered as Kledaka kapha. ${ }^{[33]}$ secretions of gastrointestinal tract which

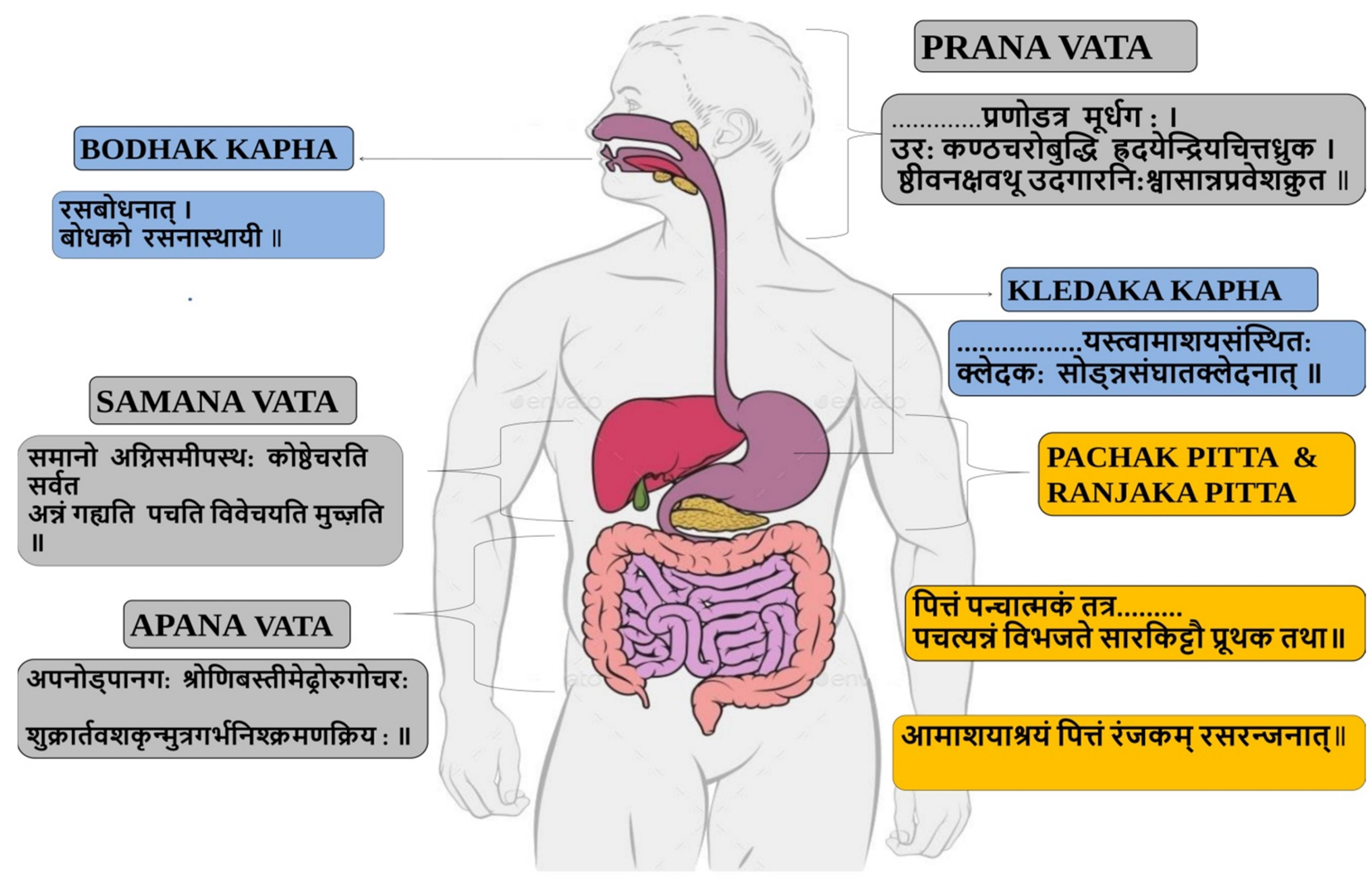

Figure 1: Role of Tridosha in different stages of digestion

\section{DISCUSSION}

Tridoshas are present throughout the Body but depending upon the site their execution will be different. Tridoshas are functional entities which are manifested in the body through their Guna (qualities) \& specific site. Equilibrium state of these Doshas are required for optimal health. Each Dosha has its own specific properties.
As we have gone through the functional importance of subtypes of these Tridoshas, we can easily understand their role specifically in process of digestion.

Tridosha maintains the whole process of Aharapachana Starting from the ingestion of the food up to the excretion of Annamala (urine $\&$ feces). As prana vata due to its Anulomana Gati (downward movement) helps the food to be swallowed. One more 
important function of Parana vata is Udagara, that is expulsion of gaseous waste from stomach. Whole Kostha is activity area of Samana vata. It induces all GI movement necessary for the digestion of food in different part of GI tract. Also it induces secretion of digestive enzymes in GI tract. when food bolus enters into Kostha it is digested by Pachaka pitta \& converted into simple absorbable. So Vijaatiya food is coverted into sajaatiya by the action of Pachaka pitta. To protect the mucosal layer of stomach from this corrosive effect of Pachaka pitta, Kledaka kapha is present in Amashaya. It also moist the food bolus for easy digestion. After the completion of digestion, food is converted into two part, one is Absorbable product \& another is waste product. These waste products are nothing but the urine $\&$ feces which must be expelled out otherwise it may retain in the body \& causes vitiation. Timely expulsion of Aharamala is a function of Apana vata which prevents the retention of waste in the body. That's how whole process of Aharapachana is governed by Tridoshas in our body.

\section{CONCLUSION}

According to Ayurvedic science the physiological function of human beings are regulated by three fundamental principles that is Tridosha Siddhanta. Our body is panchabhoutika (made up of pancha mahabhuta), each body entity is nourished by intake of food which is also made up of panchmahabhutas. For that it must be converted in to simple \& absorbable form, which is carried out by process of digestion.

After detailed discussion on all doshas, it is concluded that all Tridoshas in their regard have their own importance in digestion process.

From above mention details of all Doshas, we can very well understand the role of Tridosha in the process of digestion.

\section{REFERENCES:}

[1] Sushruta samhita, Kaviraj Ambikadutta Shastri, Vol -1, Sutrasthana $15 / 48$, page no 84 ,chaukhamba Sanskrit Sansthan Varanasi.

[2] Charak samhita, Brahmanand tripathi, Vol -1, sutrasthana 27/347.348, edition 2006. chaukhamba Prakashan Varanasi.

[3] Astanga Hridaya, Brahmanand tripathi, sutrasthana $13 / 15$, page no 186, chaukhamba sanskrit pratishthan Delhi.

[4] charaka samhita, Acharya vidyadhar shukla, Prof. Ravi Dutt Tripathi, Vol -1 , sharira sthana 6/16, Page no. 756 , 
chaukhamba Sanskrit Pratishthan

Delhi.

[5] Charak Samhita, Acharya Vidyadhar Shukla, Prof. Ravi Dutt Tripathi, Vol -1, Sharir sthana 6/17, Page no. 756, chaukhamba Sanskrit Pratishthan Delhi.

[6] Charak samhita, Acharya vidyadhar shukla, Prof. Ravi Dutt Tripathi, Vol 1, Sutra sthana 20/9, Page no. 292, chaukhamba Sanskrit Pratishthan Delhi.

[7] Charak Samhita, Acharya vidyadhar shukla, Prof. Ravi Dutt Tripathi, Vol 2 , chikitsa sthana 28/6, Page no. 687, chaukhamba Sanskrit Pratishthan Delhi.

[8] Sushruta samhita, Kaviraj Ambikadutta Shastri, Vol -1, Nidana sthana 1/13, page no 217, chaukhamba Sanskrit Sansthan Varanasi.

[9] Astanga samgraha, Kaviraj Atrideva Gupta, Vol - 1, sutrasthana 20/4, page no 160,chaukhamba krishnadas academy Varansi.

[10] Astanga Hridaya, Brahmanand tripathi, sutrasthana $12 / 9$, page no 172, chaukhamba sanskrit pratishthan Delhi.
[11] Sushruta samhita, Kaviraj Ambikadutta Shastri, Vol -1, Sutrasthana 35/33, page no 173 ,chaukhamba Sanskrit Sansthan Varanasi.

[12] Astanga samgraha, Kaviraj Atrideva Gupta, Vol - 1, sharira sthana 5/40, page no 301, chaukhamba krishnadas academy Varansi.

[13] Astanga hridaya, Brahmanand tripathi, sutrasthana $12 / 11$, page no 172, chaukhamba sanskrit pratishthan Delhi.

[14] Astanga hridaya, Brahmanand tripathi, sutrasthana $12 / 12$, page no 186, chaukhamba sanskrit pratishthan Delhi.

[15] Astanga samgraha, Kaviraj Atrideva Gupta, Vol - 1, sutrasthana 20/6, page no 161, chaukhamba krishnadas academy Varanasi.

[16] Sushruta samhita, Kaviraj Ambikadutta Shastri, Vol -1, Sutrasthana 21/12, 13 , page no 116 ,chaukhamba Sanskrit Sansthan Varanasi.

[17] Madhabendranath pal, The Tridosha Theory, Ancient science of life, VolX January 1991, page 144-155.

[18] Aparna singh, Analysis of concept of Aaharpaka in ayurveda, journal 
of Agricultural science and technology, vol-2, issue 1,January 2013

[19] Pandey K, chaturvedi G, eds. Vatavyadhi chikitsa Adhyaya, charaka samhita. Varansi, India Chaukhamba bharati Academy, 2015; page no.775 Reprint.

[20] Shastri A.D. eds, Vatavyadhi Nidana Adhyaya, Ayurveda Tatwa Sandipika Hindi commentry, sushruta samhita, varansi India, chaukhamba sanskrit Sansthan, edition 2014, page no.296

[21] Pritam moharana, A critical review of prana vayu in the modern perspective, international journal of ayu pharm chem, vol 9 issue 1 , july 2018.

[22] Gupta A.D. Eds, Doshabhediya Adhyaya, Astanga Sangraha, Varansi, India, Chaukambha Krishnadas Academy; 2012: 160 Reprint.

[23] Pritam moharana, A critical review of Samana vayu in the modern perspective, international journal of ayu pharm chem, vol 9 issue 2, September 2018.

[24] Charak samhita, Acharya vidyadhar shukla, Prof. Ravi Dutt Tripathi ,
Vol -2, chikitsa sthana 28/6, Page no. 688, chaukhamba Sanskrit Pratishthan Delhi.

[25] Sushruta samhita, Kaviraj Ambikadutta Shastri, Vol -1, Nidana sthana $1 / 13$, page no 218 , chaukhamba Sanskrit Sansthan Varanasi.

[26] Kamath Nagraj, Critical analysis of Apana vata in terms of shareera Kriya, Unique journal of Ayurvedic and herbal medicines, 04(01), February 2013, page.no.21-25

[27] Shastri A.D.eds, Vranaprashna adhyaya, Ayurveda Tatwa Sandipika Hindi Commentary, Susruta samhita, varanasi india, Chaukhamba sanskrit Sansthan, edition 2010. Page no.115

[28] Gupta A.D. Eds, Doshabhediya Adhyaya, Astanga Sangraha, Varansi, India, Chaukambha Krishnadas Academy; 2012: 160 Reprint.

[29] Gupta A.D. Eds, Doshabhediya Adhyaya, Astanga Sangraha, Varansi, India, Chaukambha Krishnadas Academy; 2012: 161 Reprint.

[30] Pritam moharana, A critical review of Pachaka pitta in the modern 
physiological

perspective,

international journal of research in ayurveda pharm, january 2019;

10(1), page no. 18-20

[31] Shastri A. D. eds, Vranaprashna adhyaya, Ayurveda Tatwa Sandipika Hindi Commentary, Susruta samhita, varanasi india, Chaukhamba sanskrit Sansthan, edition 2010. Page no.116

[32] Gupta A.D. Eds, Doshabhediya Adhyaya, Astanga Sangraha, Varansi, India, Chaukambha Krishnadas Academy; 2012: 161 Reprint.

[33] Mula Ram, A critical review of kledaka kapha of ayurveda in the modern physiological perspective, Indian journal of applied research, vol 10, july 2020

[34] Charak Samhita, Acharya Vidyadhar Shukla, Prof. Ravi Dutt Tripathi, Vol -1, Sutra sthana 30/26, Page no. 336, chaukhamba Sanskrit Pratishthan Delhi.

[35] Shastri A.D.eds, Doshadhatumala kshyavriddhi vigyaaniyaadhyaya, Ayurveda Tatwa Sandipika Hindi Commentary, Susruta samhita, varanasi india, Chaukhamba sanskrit Sansthan, edition 2010. Page no.84
[36] Kaviraj Ambikadutta Shastri, Sushruta samhita, chaukhamba Sanskrit Sansthan Varanasi, India, Vol -1, Sutrasthana 46/3, page no 233

[37] Charak samhita, Acharya vidyadhar shukla, Prof. Ravi Dutt Tripathi, Vol -1, Sutra sthana 27/5, Page no. 228, chaukhamba Sanskrit Pratishthan Delhi.

[38] Dr. Nandini dhargalkar, Text book of physiology in ayurveda, Chaukhamba sanskrit series office, varanasi, edition 2008, vol-2, sarira poshan adhyaya, page no. 7

[39] Charak samhita, Acharya vidyadhar shukla, Prof. Ravi Dutt Tripathi, chaukhamba Sanskrit Pratishthan Delhi Vol -1, Sutra sthana 28/4, Page no. 232.

[40] Dr. Nandini dhargalkar, Text book of physiology in ayurveda, Chaukhamba sanskrit series office, varanasi, edition 2008, vol-2, sarira poshan adhyaya, page no. 7

[41] Kaviraj Ambikadutta Shastri, Sushruta samhita, chaukhamba Sanskrit Sansthan Varanasi, India, Vol -1, Sutrasthana 15/3, page no 136. 
[42] Acharya vidyadhar shukla, Prof.

Ravi Dutt Tripathi, Charak samhita, chaukhamba Sanskrit Pratishthan Delhi Vol -2, Chikitsa sthana 16/6, Page no. 238.

[43] Dr. Nandini dhargalkar, Text book of physiology in ayurveda, Chaukhamba sanskrit series office, varanasi, edition 2008 , vol-1, page no. 369

[44] Acharya vidyadhar shukla, Prof. Ravi Dutt Tripathi, Charak samhita , chaukhamba Sanskrit Pratishthan Delhi Vol -2, Chikitsa sthana 28/6, Page no. 234.

[45] Kaviraj Ambikadutta Shastri, Sushruta samhita, chaukhamba Sanskrit Sansthan Varanasi Vol -1, Nidana sthana 1/33, page no 240 .

[46] Brahmanand tripathi, Astanga hridaya, chaukhamba sanskrit pratishthan Delhi, sutrasthana 12/13, page no 186. 